\title{
Investigation the need to teach the characteristics of the development of parliamentarism in Latin America as part of education
}

\section{Investigar la necesidad de enseñar las características del desarrollo del parlamentarismo en América Latina como parte de la educación}

\section{Larisa Lvovna Norden}

Candidate of historical sciences, lecturer, Department of General History, Institute of International Relations, Kazan Federal University

ORCID ID 0000-0002-8410-7694

* Correspondence

Email: NordenLL@mail.ru 


\section{Summary}

The article highlights the history and features of parliamentarism development in the Latin America countries. In addition, the need for training on the subject and the effect of increasing students and educators' awareness in this field is examined. This process was lengthy, replete with the examples of various social groups, political trends and parties struggle intensity increase. Since the beginning of the 19th century, there have been almost no favorable conditions for the practical implementation of democratic government in the countries of Latin America, and the institutionalization of the party system has not taken place yet. However, there have been exceptions to the general rule in the history of Latin America. Chile and Argentina were such an example. The success of democratic transformations in the countries of the region depended on various reasons: a) whether the country had a democratic experience in its past; b) the conditions for the political and economic development of this country to develop representative institutions in the future; c) the importance of the parties in the political course development and the adoption of state decisions. The results of democracy and parliamentarism development in the states of Latin America are rather complicated by the turn of the 20th and 21st centuries. On the one hand, the last decades of the XX-th century and the beginning of this century was marked by the democratization of political life, reforms, and the replacement of military regimes with civilian governments. Since the beginning of the 60-ies, they started the process of democratization and formation of independent island states in the Caribbean and Central America. Despite the successful development of the economy, culture, education, the presence of a large middle class in Argentina, the military governments overcame civilian ones in the 30-70-ies. Therefore, it is needed to consider this aspect as a part of education system to improve the educators' level.

Keywords: Latin America, XIX - XX centuries, Education system, Parliamentarism, Society, Democracy.

\section{Resumen}

El artículo destaca la historia y las características del desarrollo del parlamentarismo en los países de América Latina. Además, se examina la necesidad de formación en el tema y el efecto de incrementar la conciencia de estudiantes y educadores en este campo. Este proceso fue largo, repleto de ejemplos de diversos grupos sociales, tendencias políticas y luchas de partidos en aumento. Desde principios del siglo XIX, casi no se han dado condiciones favorables para la implementación práctica del gobierno democrático en los países de América Latina, y la institucionalización del sistema de partidos aún no se ha dado. Sin embargo, ha habido excepciones a la regla general en la historia de América Latina. Chile y Argentina fueron un ejemplo. El éxito de las transformaciones democráticas en los países de la región dependió de varias razones: a) si el país tuvo una experiencia democrática en su pasado; b) las condiciones para el desarrollo político y económico de este país para desarrollar instituciones representativas en el futuro; c) la importancia de los partidos en el desarrollo del rumbo político y la adopción de decisiones estatales. Los resultados del desarrollo de la democracia y el parlamentarismo en los estados de América Latina son bastante complicados por el cambio de siglo XX y XXI. Por un lado, las últimas décadas del siglo XX y principios de este siglo estuvieron marcadas por la democratización de la vida política, las reformas y la sustitución de regímenes militares por gobiernos civiles. Desde principios de la década del 60, iniciaron el proceso de democratización y formación de estados insulares independientes en el Caribe y Centroamérica. A pesar del exitoso desarrollo de la economía, la cultura, la educación, la presencia de una gran clase media en Argentina, los gobiernos militares superaron a los civiles en los años 30-70. Por tanto, es necesario considerar este aspecto como parte del sistema educativo. 
Palabras clave: América Latina, siglos XIX - XX, sistema educativo, parlamentarismo, sociedad, democracia.

\section{Introduction}

The history of the Latin America countries is marked by the confrontation between conservative, reformist and radical alternatives for the society development. The interests of various social groups of the population, political movements and parties interacted in these large-scale processes. There was a search for solutions to political, social, and economic problems during this struggle. Of course, these processes had their own characteristics, national variations abounded with sharp turns, and changes in the balance of the forces involved in them.

Latin America is a unique region whose historical development has been influenced by many factors. Let's name just a few of them. So, the integration of political, social, economic structures into the orbit of new ones has become the peculiarity of the region. This ability to integrate has accelerated the involvement of Latin American countries and progress, made them more susceptible to new perceptions. This factor also took place in the development of the economy, culture, ideology, and social psychology. At the same time, it was possible to observe the extraordinary vitality of traditional structure elements in new conditions.

Secondly, the countries of the Latin American region had their own specifics and the process of nation development. It is worth remembering the diversity of racial and ethnic components, which was the result of the of the Indian population mixing with the immigrants from Europe and Africa.

Third, we must consider the weakness of the Latin American economy, especially in the nineteenth century, and, thus, the weakness of its own national bourgeoisie. It is necessary to remember the extraordinary vitality of the patriarchal-Caudillian elements, and the clannishness of society.

Fourthly, the significant role of the Catholic Church was a characteristic feature of public life in Latin America. It manifested itself in the development of culture, enlightenment, the introduction of the Indian population to the values of European civilization, and in a national mentality development.

\section{Methods}

The historical and genetic method was applied by the author in the study of certain phenomena and concepts of Latin America socio-political history folding, development, and transformation. With the help of the comparative historical method, it became possible to restore the mechanism of socio-political processes in Latin America, to reveal the role of objective and subjective factors, progressive and regressive tendencies, common and singular, that determine the characteristic features of Latin American parliamentarism development.

\section{Results and Discussion}

Almost from the very beginning of their statehood acquiring, the young countries of Latin America adopted the constitutions based on the most advanced political and legal ideas of that time. Almost all the constitutions of the young Latin American states (excluding Brazil) consolidated their republican structure. At the same time, the issue of administrative centralization degree caused sharp disagreements in many countries. Often these disputes became the cause of long-term armed clashes. In general, this issue was then decided in favor of federalism.

The organization of government bodies and the structure of the first Latin American constitutions were influenced by North American and European constitutionalism. They contained many democratic provisions and declarations of human and civil rights. However, the transfer of 
these norms and practices was of a mechanical nature, and therefore the war for independence did not lead to fundamental changes in the social structure of political and legal traditions for any Latin American country.

Venezuela became the first state to adopt a constitution (1811). This constitution turned out to be based on the US Constitution provisions. The Constitution of 1811 established the federal structure of the republic and the principle of separation of powers. The Bolivian Constitution (1826) provided for a strong centralization of power. For a long time the most significant and effective constitutions were the constitutions of Argentina (1853) and Mexico (1853). The Federal Republic of Argentina provided for a representative form of government and was also based on the principle of separation of powers. Legislative power was vested in a bicameral congress; executive - to the president elected for six years on the basis of two-stage elections (and without the right of immediate re-election). The judiciary power was represented by the Supreme Court. The federal courts were subordinate to it. This authority considered all conflicts between the provinces, since the Constitution prohibited such hostilities. For the first time in history, the Constitution of Argentina legally determined the legal status of foreigners in the state. The compromise nature of the Mexican constitution (1857) was explained by the predominance of representatives from moderate liberals and right-wing politicians at the Constituent Congress, where the law was passed. Despite the fact that there was a certain "gap" between the real situation and the provisions declared in the Constitution within the political and legal practice of Mexico at that time, the state constitutional law had a progressive meaning both for the development of parliamentarism and for the economy development. According to the Brazilian Constitution of 1891, a federal structure was also established in the country. Each state has broad rights. However, this did not mean a high level of democracy in power structures. The broad rights of each state concealed the interests of the planters and the local bourgeoisie, as well as foreign companies associated with it. However, the Brazilian Constitution proclaimed democratic rights and freedoms, which created the basis for the democratization of the entire political life of the state and society in the future.

In the context of the socio - political struggle of the 1820-1830-ies not all principles and norms laid down in the first Latin American constitutions were implemented in practice. During this time, rival factions emerged, providing the basis for the emergence of Latin American conservatism and liberalism and the formation of political parties in the near future. The social base of conservatism was monarchists, adherents of a unitary state structure and strict bureaucratic management, latifundists, and the Catholic Church. Liberals represented the interests of some large landowners, local business circles, and the opponents of bureaucratic centralization and unitarianism - the federalists. Conditional differences between parties became significant when the struggle for state power began. The parties relied on the caudillo leader and seized power through a coup d'état, creating an authoritarian regime. For a long period, political parties in the states of Latin America became not an instrument of democracy and parliamentarism, but a component of a specific system - caudillism. The caudillo's power relied on the army, and soon after gaining independence, military dictatorships were established in some states. However, most often, the caudillo's power did not last long, since it depended largely on the privileges that the army retained.

Political instability in the states of Latin America led to constitutional instability. Caudillos changed; new constitutions were adopted. This phenomenon has passed into the XX-th century. At first, superficial glance, the constitutions of Latin American states retained democratic forms: selective government, democratic rights and freedoms of citizens, the very principle of separation of powers. However, they were of a declarative nature. The imposed restrictions impeded the implementation of universal suffrage. In the struggle for power, in order to strengthen statehood and political stability, the presidents introduced the "state of siege", in which the effect of constitutional norms and guarantees was suspended. 
Thus, the countries of Latin America created specific state and legal institutions, with which they existed until the middle of the 20 -th century.

Since the 1980-ies the process of building a consolidated representative democracy began in Latin America (O'Donnell \& Schmidter, 1986), but the development and establishment of representative institutions took place with great difficulties. The mechanisms of effective expression of social groups and each voter interests by a political party are limited to a certain extent. The weakness of party systems in the new democracies of the Latin American continent is compounded by the executive power tendency to control the activities of parliamentary factions and political parties. The mass media also contributed to this to a large extent. In this case, the democratization of the political system may not be fully realized and it becomes possible to intervene in the politics of power structures and, thus, to establish an authoritarian power. A stable party system is the guarantor of the consolidation of the democratization processes. Only with the help of a stable party system is it possible to transfer the population interests into the political sphere. The stability of a party system can only be achieved if the following conditions are met: 1) compliance with the rules of inter-party competition; 2) the presence of a close stable relationship with voters; 3 ) the determining role of parties in the ruling elite development; 4) a clear structure of parties and procedures prescribed by the rules of internal party activity minimizes the possibility of subordinating the party to an ambitious leader (Mainwaring \& Scully, 1995).

In this regard, the examples of Argentina and Chile are unique, since the main political parties "survived" authoritarian regimes in these countries despite difficult conditions. At the end of the twentieth century against the background of the consequences of the previously carried out neoliberal reforms in political life, the next contradictions intensified, which were rooted in the 19th century. They consisted in the recreation of patron-client populist parties under the new conditions (as was the case in Argentina). Society as a whole and public organizations showed distrust of traditional parties of any kind and of political institutions in general. The effectiveness of democracy consolidation depended on many factors. Despite the fact that the party-political systems of Chile and Argentina were formed in the late 19-th and early 20-th century, however, they differed in their democratic tradition and in institutionalization degree. The American researcher Seymour M. Lipset assessed the level of democratization development in the countries of the Latin American region: "Since the beginning of independence during the first quarter of the XIX-the century and for ... decades of independent development ... there were no conditions for the implementation of democratic methods of government ... societies ... were unable to create or institutionalize competitive party systems. The organizations calling themselves parties ... for the most part manifested themselves as unstable populist movements, regional groupings or personalist entities that were unable to survive the crisis" (Lipset, 2000). This statement does not quite fit in Chile. From the second half of the XIX-th century Chilean society was distinguished by a high degree of politicization and competitiveness of political parties, by their mass character. This distinguished the country's political system from other countries in the region and made it similar to those that were developed in Western European states. For a century and a half before the military coup of 1973, Chile's political system was committed to a democratic tradition. The country's political life includes strict respect for the law, democratic rights, and the transparent nature of elections. In Argentina, during the period of 1950 - 1960 the army seized power four times, and the Peronist regime had the features of a military dictatorship.

There are several factors that have influenced the democratic nature of Chile's political development:

A) The difference in the culture of political leadership: popularity and respect for the presidents by society, the possession of resources that made the power strong, the desire of leaders not to abuse power (Valenzuela, 1990);

B) Political structures were not constrained by patron-client relations. Politics in the country was "done" by professionals with some experience in the political sphere, the leaders of the state came to power through elections and the support of political parties (Valenzuela, 1990);

C) The effectiveness of the political course, the successful development of the economy (Peeler, 1995) led the ruling elite to realize the advantages of democracy for the state; 
D) The ability of leaders to lead the army beyond the political struggle;

E) The ruling elite agreed to follow the democratic tradition, for the sake of their own political well-being, in the conditions of the electorate expansion at the expense of new voters.

Until 1973, Chile had a strong institutionalized, adversarial party system. At the same time, the political parties of the "neighbors" were formed as personalistic and were extremely unstable. J. Sartori concluded that the Chilean party system developed along the "Western European path of party-political structure evolution" (Sartori, 1976). Besides, the formation of parties in Chile began before the emergence of a centralized bureaucratic state apparatus. Accountability to voters has strengthened representative institutions. Informal ties played an important role in political practice in those countries where the bureaucratic system was formed before the emergence of parliaments and strong political parties. This reinforced corporatist and authoritarian tendencies.

In the 1960-ies the crisis of the state of compromise began to manifest itself. Traditional political forces found themselves isolated. The existing party-political structure began to malfunction (Garreton, 1986). The disruption of the balance of power caused the political crisis of the 70 -ies.

Despite the successful development of the economy, culture, education, the presence of a large middle class in Argentina, the military governments overcame civilian ones in the 30-70-ies. The reasons for political instability - the peculiarities of the party system and the interest representation system. The political forces in power saw themselves as mass movements rather than political parties until the 1980-ies. In this case, the interests of the opposition "suffered", the elections were ignored, and the leader was put at the forefront, not the political platform of the parties. Cohesion into political groups (future political parties) around a charismatic personality led to the dominance of authoritarian features of state power. The authoritarian tradition largely determined the nature of political representation. This was determined by the long dominance of regional caudillos, provincial separatism, late national consolidation, the struggle between the supporters of unitarianism and the adherents of federalism, military clashes and the absence of national parties. The Constitution of 1853 consolidated the powers in the hands of the executive bodies (A semi-parliamentary form of government was established in Chile during the early 1890ies). Party groupings turned out to be weak, operated only at the provincial level and were devoid of competition. From the second half of the XIX-th century they became the factions of rival oligarchic clans and lacked mass support. The interests of the oligarchs were focused on access to the center of decision-making and material wealth. Most of the society was excluded from political life. Business circles and industrial workers joined the social and political life of the country at the turn of the 19-th and 20-th centuries. The emergence and expansion of the "middle class" entailed the democratization of the political regime. Mass migration from European countries also played a role. The oligarchy did not seek to share power; the economy, the army, the press, and universities remained under its control. The law on secret ballot, the rules for submitting ballots and registering candidates were passed only in 1912. Since that time, the party of Argentine radicals began to play the role of "the main driving force of political democratization" (Vorozheykina,1996). For a long time, the radicals were not completely free in their actions, and they did not seek to violate the established "game rules." The situation began to change towards the end of the 1920-ies with the arrival of a new generation of professional politicians. Conservatives did not "fit" into the prevailing political realities and fiercely tried to defend their interests. In the 30-ies the authoritarian corporatist tendencies intensified in the country again, the logical conclusion of political processes was the approval of perronism. He determined the further development of the social and political life of Argentina and influenced the formation of modern political parties. The era of mass politics began in the middle of the twentieth century. Import substitution industrialization brought the urban population to the polls (industrial workers who arrived from the 
provinces of rural migrants, the middle strata). They turned into a political force that could not be ignored. None of the political parties could absorb a wide sector of new voters. The military and national bourgeoisie experienced a shortage of political representation, whose political and economic interests were infringed upon by foreign capital. Riding this wave, Peron came into politics, taking full advantage of populist techniques and the methods to unite heterogeneous elements into a single movement and appealing to the interests of the entire nation. The Peronist movement became the most massive in the history of Latin America. Perón was skeptical of the political parties in Argentina, saw their weakness and inability to unite society. Since the first half of the 1940-ies he began to organize trade unions, which included "new" urban workers. The regime was supported by women's and youth organizations and the national bourgeoisie. The mass Peronist party was the part of the state machinery and played a consolidating role. Historians and political scholars believe that populism is more likely in the countries with less developed political systems. In this case, the state is unable to protect the interests of different social groups. After the coup of 1955, Argentina had to endure a tense confrontation between properonist and anti-peronist forces, which led to the establishment of an authoritarian-bureaucratic regime.

The events of 1970-ies in Chile and Argentina greatly influenced the development of their party-political structures and parliamentary institutions. This influence continued after the return of states to democratic rule, when traditional parties resumed their political participation. Society had high hopes for them, expecting the expansion of democracy. It soon turned out that political parties, both of Argentina and Chile, did not fully cope with the task of effective representation of the interests of various social groups. This can be explained by the new challenges of the time neoliberal reforms, globalization, the action of other external factors, and the limitations of the "traditional" institutions of democracy and power. This situation becomes relevant at the beginning of the XXI-st century, both for the most developed countries of Latin America, and for the entire region as a whole.

\section{Conclusions}

1. The success of democratic transformations in the countries of the Latin American region depends on the past democratic experience, the conditions for the political and economic development of the country to form and develop representative institutions in the future, the importance of political parties in government decision making.

2. Development of democracy and parliamentarism took place in the conditions of the significant influence of caudillism and violencia on the social and political life of the countries of the region in the XIX - XX centuries.

3. Since the 1980-ies the process of a consolidated representative democracy development began in Latin America. However, the weakness of party systems in the new democracies of the Latin American continent was compounded by the executive power propensity to control the activities of parliamentary factions and political parties.

4. In terms of democracy, parliamentarism, the party-political system development, Argentina and Chile are unique, which had to survive authoritarian regimes. The experience of these states had both common features and national specifics.

5. Initially borrowed from the experience of the United States and Western European states, democratic institutions and ideas have become an integral part of the historical heritage of Latin America and have been able to survive sometimes in the most unfavorable conditions, reviving at the slightest positive changes.

\section{Summary}

Latin American countries of the XIX - XX centuries did not live long in a democracy. The history of Latin America is full of military coups and the periods of dictatorships. It is all the more striking that after many years of authoritarian rule and lawlessness, the institutions of political democracy have shown a stable capacity for revival. Originally borrowed from the Western model, these institutions and ideas have become an important component of the historical heritage of the peoples of the Ibero-Caribbean region and their modern socio-political life over the course of two 
centuries. As a well-known expert in the history and culture of Latin America Ya.G. Shemyakin justly remarked the following: "Adapting on Latin American soil, they united with the old democratic tradition ... "communeros" and tyrannical fighters, the legacy of the ineradicable spirit of municipal self-government - the cabildo. The emerging "mestizo" ideological and political tradition has definitely taken on the precious quality of the Spanish and Spanish American democratic tradition to be preserved in any, even in the most unfavorable conditions ... invariably awakening to a new life with the slightest changes for the better" (Shemyakin, 1987). Thus, the Western tradition of political democracy, transforming in the conditions of the region, has become a Latin American tradition.

\section{Acknowledgements}

The work is performed according to the Russian Government Program of Competitive Growth of Kazan Federal University.

\section{References}

Garreton, M.A. (1986). The Political Evolution of the Chilean Military Regime and Problems in the Transition to Democracy. Baltimore - London, p. 97

Lipset, S.M. (2000). The Indispensability of Political Parties. - Journal of Democracy. New York, №11, p.51

Mainwaring, S., Scully, N.R. (1995). Party Systems in Latin America. - Building Democratic institutions. Stanford, p. 5

Peeler, J. (1995). Building Democracy in Latin America. Boulder - London, 1998, p. 44; A.I. Stroganov. The latest history of Latin America. M., p. 19

Sartori, G. (1976). Parties and Party System: a Framework from Analysis. New York, pp.162-163

Shemyakin, Ya.G. (1987). Latin America: traditions and modernity. - M., p. 134

The concept of "consolidated democracy" was first disseminated in the work of political scientists G. O'Donnell and F. Schmidter "Transition from Authoritarian Government" (1986)

Valenzuela, A. (1990). Chile: Origins, Consolidations, and Breakdown of a Democratic Regime. Politics in Developing Countries. Comparing Experiences with Democracy. Boulder, p.60

Vorozheykina, T.E. (1996). The specifics of civil society in Argentina. - ME and MO, 6, p. 90 